\title{
Pemodelan Sistem Informasi Persediaan Barang Milik Daerah Se Kabupaten Kotawaringin Timur Menggunakan Archimate Enterprise Architecture
}

\author{
Slamet Riyadi ${ }^{1}$ \\ ${ }^{1}$ Sistem Informasi, Fakultas Ilmu Komputer Universitas Darwan Ali, Sampit \\ E-mail: *1 slamet riau@yahoo.com, ${ }^{1}$ slamet.riau2@gmail.com
}

\begin{abstract}
Abstrak - Pengelolaan aset daerah/Barang Milik Daerah bukan merupakan pekerjaan yang mudah, terbukti dari masih banyaknya pengecualian kewajaran atas nilai aset pemerintah dan pemerintah daerah dalam opini BPK-RI atas laporan keuangan Pemerintah. Pemerintah Daerah mengalami kesulitan dalam pengelolaan aset sehingga menyajikan aset daerah kurang atau tidak wajar.

Tanpa sebuah visi, infrastruktur TI tidak akan dapat mendukung proses bisnis, dan sebaliknya bisnis tidak akan optimal tanpa dukungan TI. Hal ini juga terjadi di BPKAD Kotawaringin Timur dimana Sistem Informasi Pengelolaan Barang yang pernaj dibuat pada tahun 2014 belum dapat diterapkan. Hal ini terjadi karena masih ada ketidak sepakatan antar pemangku kepentingan pada proses bisnis, aplikasi, maupun pada teknologi yang digunakan

ArchiMate merupakan standar dari Open Group, adalah bahasa pemodelan yang terbuka dan independen untuk Arsitektur Perusahaan yang didukung oleh berbagai vendor dan perusahaan konsultan. Spesifikasi ArchiMate menyediakan instrumen untuk memungkinkan Arsitek Perusahaan untuk menggambarkan, menganalisis, dan memvisualisasikan hubungan antara domain bisnis dengan cara yang jelas.

Pemodelan Enterprise Architecure yang sudah dibuat sudah menggambarkanTata Kelola yang dibutuhkan dalam hal pengelolaan barang milik daerah. Oleh karena itu penerapan TI nantinya harus mengacu kepada pemodelan ini. Hal ini juga untuk menghindari resiko kegagalan penerapan IT seperti yang sudah terjadi sebelumnya
\end{abstract}

Kata Kunci - Enterprise Architecture, Archimate, Barang Milik Daerah

\footnotetext{
Abstract - Management of regional assets is not an easy job, it is evident from the still many reasonable exceptions to the value of government and local government assets in the BPK-RI opinion on the Government's financial statements. Local Governments have difficulty in managing assets so that they present less or unnatural regional assets.

Without a vision, IT infrastructure will not be able to support business processes, and vice versa business will not be optimal without IT support. This also happened at BPKAD East Kotawaringin where the assets Management Information System that had been created in 2014 could not yet be implemented. This happens because there are still disagreements among stakeholders.

ArchiMate is a standard of the Open Group, is an open and independent modeling language for Enterprise Architecture supported by various vendors and consulting firms. The ArchiMate specification provides instruments to enable Corporate Architects to describe, analyze, and visualize relationships between business domains.

Architecure Enterprise Modeling that has been made already illustrates the Governance Arrangements needed in terms of the management of regional property. Therefore the application of IT will have to refer to this modeling. This is also to avoid the risk of failing to implement IT as before
}

Keywords - Enterprise Architecture, Archimate, Asstets Management 


\section{PENDAHULUAN}

Pengelolaan aset daerah/Barang Milik Daerah bukan merupakan pekerjaan yang mudah, terbukti dari masih banyaknya pengecualian kewajaran atas nilai aset pemerintah dan pemerintah daerah dalam opini BPK-RI atas laporan keuangan Pemerintah. Pemerintah Daerah mengalami kesulitan dalam pengelolaan aset sehingga menyajikan aset daerah kurang atau tidak wajar. Kurang tertibnya pengelolaan Barang Milik Daerah terhadap inventarisasi dan penilaian yang ditemukan di lapangan diantaranya yaitu :

1. Belum terlaksananya pemuktahiran pembukuaan BMD pada sistem informasi manajemen BMD

2. Tidak jelasnya status aset dan kurangnya tingkat akurasi penilaian aset yang dikelola.

3. Kurang tertibnya mekanisme inventarisasi Barang Milik Daerah (BMD) oleh Pengguna Barang dan kuasa Kuasa Pengguna Barang;

4. Belum optimalnya pemanfaatan dan pemindahtanganan.

Sudah menjadi rahasia umum bahwa tata kelola organisasi yang baik memerlukan penerapan Teknologi Informasi yang baik. Banyak organisasi mengeluarkan banyak biaya untuk membangun ICT (Information and Communicatian Technology), tetapi tidak memperoleh imbal balik [1].

Kegagalan dalam penerapan sistem informasi seringkali disebabkan karena tidak ada perencanaan yang matang yang meliputi organisasi secara komprehensif. Penerapan hanya dilakukan berdasarkan kebutuhan sesaat saja tanpa adanya perencanaan menyeluruh dan hanya untuk satu fungsi tertentu saja dari organisasi. Tanpa sebuah visi, infrastruktur TI tidak akan dapat mendukung proses bisnis, dan sebaliknya bisnis tidak akan optimal tanpa dukungan TI[2]. Hal ini juga terjadi di BPKAD Kotawaringin Timur dimana Sistem Informasi Pengelolaan Barang yang pernaj dibuat pada tahun 2014 belum dapat diterapkan. Hal ini terjadi karena masih ada ketidak sepakatan antar pemangku kepentingan pada proses bisnis, aplikasi, maupun pada teknologi yang digunakan.

Arsitektur Enterprise merupakan dasar terbaik untuk organisasi menggambarkan strategi bisnis dan pengembanganya melalui TI[3]. Arsitektur Enterprise juga dapat digunakan untuk mengatasi gap yang ada saat ini, yaitu dengan menggambarkan kondisi saat ini serta kondisi yang diharapkan.

Paradigma service orientation (berbasis layanan) telah dipertimbangkan menjadi salah satu paradigma arsitektur terpenting yang muncul dalam beberapa tahun terakhir [4]. Bersama dengan paradigma ini, sejumlah bahasa pemodelan berbasis layanan dan kerangka kerja telah didefinisikan untuk menggambarkan dan mengomunikasikan keputusan arsitektur perusahaan[5]. Salah satu contoh yang paling menonjol adalah ArchiMate, yang mengadopsi konstruksi "layanan" sebagai struktur elemen dasar untuk tiga lapisan arsitektur perusahaan: Bisnis, Aplikasi, dan Teknologi[6].

ArchiMate merupakan standar dari Open Group, adalah bahasa pemodelan yang terbuka dan independen untuk Arsitektur Perusahaan yang didukung oleh berbagai vendor dan perusahaan konsultan. Spesifikasi ArchiMate menyediakan instrumen untuk memungkinkan Arsitek Perusahaan untuk menggambarkan, menganalisis, dan memvisualisasikan hubungan antara domain bisnis dengan cara yang jelas[7].

\section{METODE PENELITIAN}

Metode yang digunakan untuk pemodelan pada penelitian ini yaitu ArchiMate Enterprises Architecture(EA). ArchiMate menyediakan visualisasi model EA dalam level enterprise (highlevel). Jika diperlukan desain yang detail maka dapat dimodelkan dengan standar BPMN(Business Process Model and Notation) untuk proses bisnis dan UML(Unified Modeling Language)untuk desain software.

ArchiMate memiliki tampilan berlapis dan berorientasi layanan pada model arsitektur. Lapisan yang lebih tinggi menggunakan layanan yang disediakan oleh lapisan yang lebih rendah. Meskipun, pada tingkat abstrak, konsep yang digunakan dalam setiap lapisan adalah serupa, kami mendefinisikan lebih banyak konsep konkret yang spesifik untuk lapisan tertentu. Dalam konteks ini, kami membedakan tiga lapisan utama: [1] [8] 


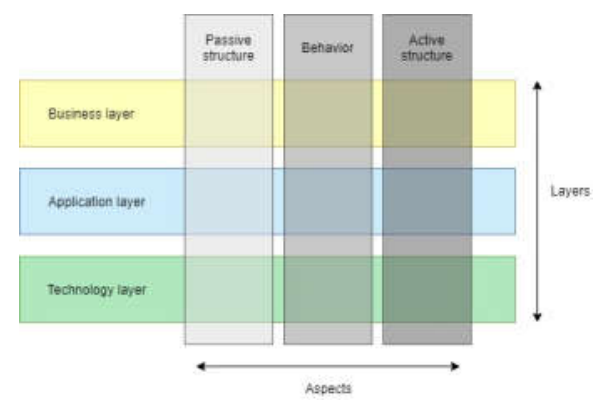

Gambar 1. Lapisan dalam Archimate Enterprise Architecture

Lapisan Bisnis adalah tentang proses bisnis, layanan, fungsi, dan peristiwa unit bisnis. Lapisan ini "menawarkan produk dan layanan kepada pelanggan eksternal, yang diwujudkan dalam organisasi dengan proses bisnis yang dilakukan oleh pelaku dan peran bisnis".

Lapisan Aplikasi adalah tentang aplikasi perangkat lunak yang "mendukung komponen dalam bisnis dengan layanan aplikasi". Lapisan Teknologi menangani "dengan infrastruktur perangkat keras dan komunikasi untuk mendukung Lapisan Aplikasi. Lapisan ini menawarkan layanan infrastruktur yang diperlukan untuk menjalankan aplikasi, direalisasikan oleh perangkat keras komputer dan komunikasi serta perangkat lunak sistem".

\section{HASIL DAN PEMBAHASAN}

Berdasarkan dari data yang diperoleh baik melalui penelaahan dokumen, observasi, maupun wawancara, maka akan dbuat tiga lapis dari konsep Archimate.

\subsection{Lapisan Bisnis}

Pada lapisan ini terdapat 3 proses utama yaitu penerimaan barang, penyaluran barang, serta inventarisasi barang. Penerimaan adalah kegiatan untuk menerima barang milik daerah yang berasal dari pengadaan atau perolehan lainnya yang sah. Proses bisnis penerimaan barang secara detail yaitu:

(1) Hasil pengadaan barang persediaan diterima oleh penyimpan barang yang dituangkan dalam Berita Acara Penerimaan Barang Persediaan.

(2) Penyimpan barang sebagaimana dimaksud pada poin (1), berkewajiban melaksanakan tugas administrasi penerimaan barang persediaan.

(3) Penerimaan barang persediaan sebagaimana dimaksud pada poin (1) selanjutnya disimpan dalam gudang atau tempat penyimpanan oleh penyimpan barang.

Penyaluran adalah kegiatan untuk menyalurkan/pengiriman barang milik daerah dari gudang ke unit kerja pemakai barang persediaan. Proses bisnis penyaluran barang secara detail dapat dijelaskan sebagai berikut:

(1) Penyaluran barang persediaan oleh penyimpan barang dilaksanakan atas dasar persetujuan Pengguna Barang atau Kuasa Pengguna Barang.

(2) Persetujuan penyaluran barang persediaan dilakukan berdasarkan permintaan penggunaan barang persediaan oleh pemakai barang persediaan melalui Nota Permintaan Barang kepada Pengguna Barang atau Kuasa Pengguna Barang melalui penyimpan barang.

(3) Kewenangan persetujuan penyaluran barang persediaan sebagaimana yang dimaksud dalam poin (1) dapat didelegasikan kepada pejabat yang ditunjuk.

Inventarisasi barang persediaan adalah kegiatan untuk melakukan penghitungan dan pencatatan barang persediaan dalam gudang/tempat penyimpanan pada saat tertentu yang dituangkan dalam Berita Acara Inventarisasi Barang Persediaan. Inventarisasi barang melibatkan kegiatan inventarisasi fisik yang dimaksudkan untuk menguji kesesuaian antara pembukuan barang persediaan dengan kuantitas dan kualitas fisik yang dilaksanakan dalam rangka akuntabilitas penatausahaan barang persediaan. 
Dari penjabaran proses bisnis diatas, selanjutnya akan dibuat model lapisan bisnis berdasarkan model archimate enterprise architecture. Pemodelan ini dimulai dengan penentuan aktor-aktor yang terlibat. Aktor tersebut yaitu Penyedia Barang, Pengguna Barang, Penyimpan Barang, serta Pemakai Barang. Penyedia Barang merupakan aktor eksternal yang memiliki event Pengadaan Barang, dimana event tersebut akan memicu proses penerimaan barang.

Business service Penerimaan Barang melibatkan aktor Pengguna Barang serta Penyimpan Barang. Pengguna Barang mengisi BAST (Berita Acara Serah Terima) barang dari penyedia Barang. setelah dilakukan serah terima selanjutnya Penyimpan Barang melakikan input penerimaan Barang

Business service Pengeluaran Barang melibatkan Pemakai Barang yang melakukan permintaan, Pengguna Barang sebagai penanggun jawab, serta Penyimpan Barang yang mengelola data barang. Proses ini dimulai dengan adanya permintaan barang dari Pemakai Barang dengan mengisi form permintaan. Selanjutnya Penyimpan barang akan mengecek ketersediaan barang tersebut, jika tersedia maka akan diajukan ke Pengguna Barang. Jika Pengguna Barang menyetujui maka barang tersebut akan diserahkan ke pemakai barang dan diinput data pengeluarannya.

Business service Inventarisasi Barang melibatkan Pengguna Barang serta Penyimpan Barang. Proses ini merupakan bentuk pertanggung jawaban Pengguna Barang kepada Negara. Proses ini dimulai dengan pengecekan secara fisik yang dilakukan oleh penyimpan barang yang selanjutnya dituangkan dalam Berita Acara Inventarisasi. Pengguna Barang akan melakukan verifikasi dan jika tidak ditemukan masalah maka penyimpan barang akan menginput data inventarisasi. Pemodelan lapisan bisnis secara lengkap terlihat pada gambar 2 dibawah ini.

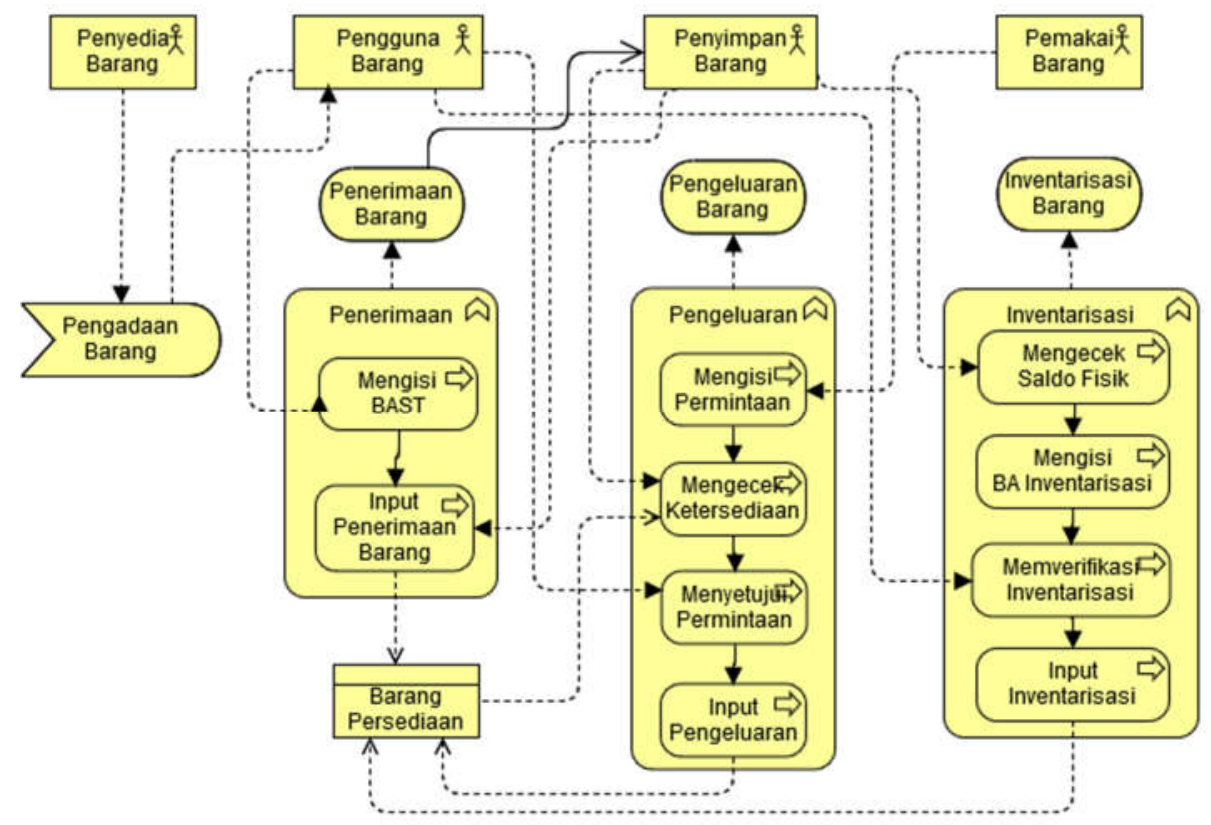

Gambar 2. Lapisan Bisnis Persediaan Barang Daerah

\subsection{Lapisan Aplikasi}

Lapisan aplikasi menggambarkan aplikasi yang dibutuhkan untuk mendukung proses bisnis yang ada. Oleh karena itu lapisan ini berkaitan langsung dengan lapisan bisnis yang ada di atasnya. Pada lapisan bisnis terdapat 3 bisnis service, maka pada lapisan aplikasi juga terdapat 3 application service yaitu Penerimaan Barang, Pengeluaran Barang, serta Inventarisasi Barang. Application service mewakili perilaku aplikasi yang didefinisikan secara eksplisit. Application service memaparkan fungsionalitas komponen ke lingkungannya. Fungsi ini diakses melalui satu atau beberapa antarmuka aplikasi.

Dari hasil pengamatan pada lapisan bisnis, maka lapisan aplikasi yang akan dibuat dapat dijabarkan sebagai berikut: 
1) Application service pada Penerimaan Barang memerlukan function Input Penerimaan Barang yang dibutuhkan oleh Penyimpan Barang. Data Penerimaan Barang tersebut selanjutnya disimpan pada objek Barang Persediaan.

2) Application service Pengeluaran Barang memerlukan 2 buah fungsi yaitu Mengecek Ketersediaan barang serta Input Pengeluaran. Fungsi Mengecek Ketersediaan diperlukan untuk memastikan bahwa barang yang diminta oleh Pemakai Barang benar-benar tersedia. Pengeluaran Barang juga akan mengubdate data Barang Persediaan.

3) Application service Inventarisasi Barang memerlukan sebuah function function yaitu Input Inventarisasi yang akan mengubah data Barang Persediaan.

Dari penjabaran diatas, maka lapisan aplikasi ini dapat dimodelkan seperti pada gambar 3 berikut ini.

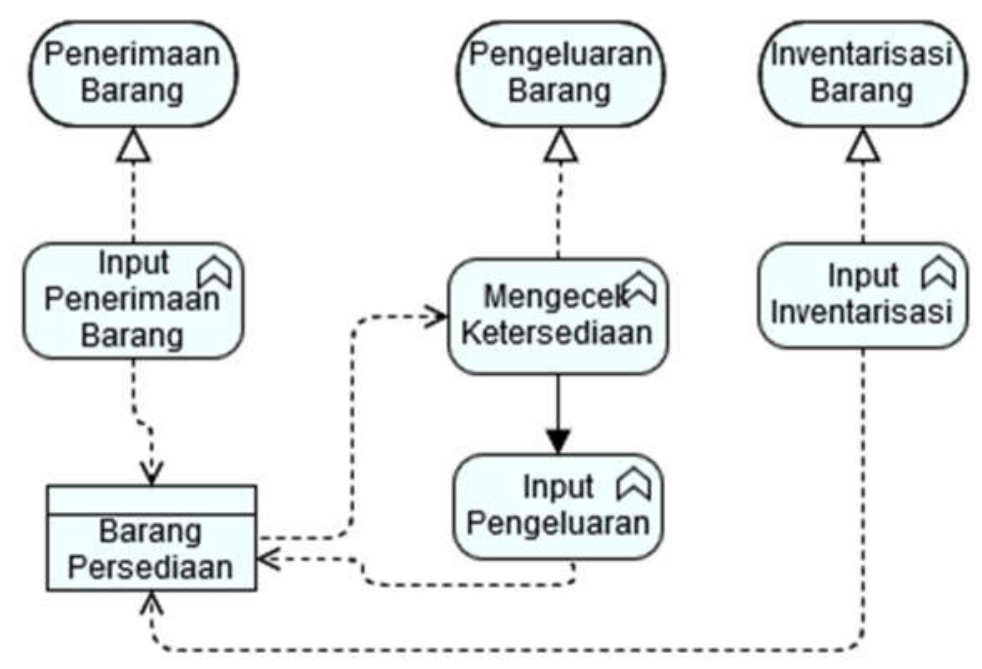

Gambar 3. Lapisan Aplikasi Persediaan Barang Daerah

\subsection{Lapisan Teknologi}

Elemen-elemen Lapisan Teknologi biasanya digunakan untuk memodelkan Arsitektur Teknologi dari perusahaan, menggambarkan struktur dan perilaku infrastruktur teknologi perusahaan[8]. Lapisan teknologi disini juga harus kompatibel dengan lapisan aplikasi yang sudah dibuat. Oleh karena itu, untuk mendukung lapisan aplikasi yang sudah dibuat sebelumnya, maka lapisan teknologi yang akan dibuat modelnya dapat dijabarkan sebagai berikut:

1) Terdapat 3 application device (perangkat) yang digunakan oleh masing-masing application service. Service yang dimaksud digambarkan dalam bentuk application component yang dapat berupa form input/output yang langsung dapat diakses oleh actor.

2) Setiap device dilindungi oleh firewall untuk mengatur lalu lintas data yang keluar masuk. Masing-masing device dapat terhubung melalui media jaringan.

3) Terdapat sebuah mainframe yang berfungsi sebagai server dari aplikasi barang persediaan. Server ini dilengkapi dengan web service, DBMS, firewall, serta terhubung ke setiap node client.

Dari penjabaran diatas, maka lapisan teknologi ini dapat dimodelkan seperti pada 4 berikut ini. 


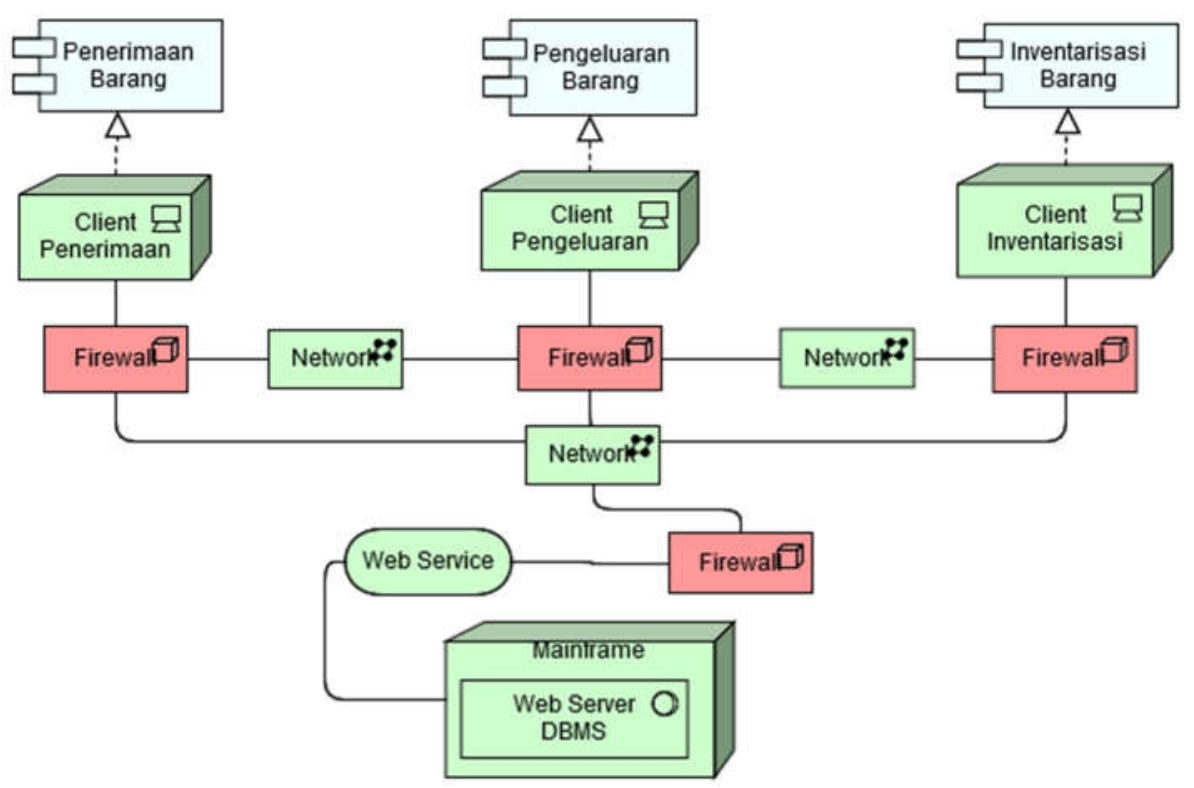

Gambar 4. Lapisan Teknologi Persediaan Barang Daerah

Pemodelan Enterprise Architecure yang sudah dibuat sudah menggambarkanTata Kelola yang dibutuhkan dalam hal pengelolaan barang milik daerah. Oleh karena itu penerapan TI nantinya harus mengacu kepada pemodelan ini. Hal ini juga untuk menghindari resiko kegagalan penerapan IT seperti yang sudah terjadi sebelumnya.

\section{SIMPULAN}

Dari hasil penelitian yang telah dilakukan dapat disimpulkan bahwa:

1. Tanpa sebuah visi, infrastruktur TI tidak akan dapat mendukung proses bisnis, dan sebaliknya bisnis tidak akan optimal tanpa dukungan TI. Hal ini juga terjadi di BPKAD Kotawaringin Timur dimana Sistem Informasi Pengelolaan Barang yang pernaj dibuat pada tahun 2014 belum dapat diterapkan. Hal ini terjadi karena masih ada ketidak sepakatan antar pemangku kepentingan pada proses bisnis, aplikasi, maupun pada teknologi yang digunakan

2. Pemodelan lapisan bisnis, lapisan aplikasi, serta lapisan teknologi sudah menggambarkan kebutuhan IT yang terkait dengan kebutuhan sistem informasi pengelolan barang milik daerah di Kab. Kotawaringin Timur.

3. Penerapan pemodelan ini kedalam Teknologi Informasi yang akan digunakan harus bertahap dimulai dengan pembenahan proses bisnis, perancangan aplikasi yang dibutuhkan, serta penyediaan teknologi yang dapat mendukung proses bisnis serta aplikasi yang digunakan.

4. Dengan adanya pemodelan ini diharapkan bahwa penerapan IT nantinya dapat benar-benar menghindari resiko kegagalan serta berhasil sesuai yang diharapkan.

\section{SARAN}

Beberapa saran untuk penelitian selanjutnya yaitu:

1. Perlunya dilakukan pengkajian yang lebih mendalam pada 3 aspek yaitu passive structure, behavior, serta active structure untuk mempertajam perspektif pemodelan.

2. Perlunya dilakukan pengkajian yang lebih mendalam dan berfokus pada lapisan aplikasi, sehingga benar-benar dapat menggambarkan kebutuhan user. 


\section{DAFTAR PUSTAKA}

[1]. P. S. Azevedo, C. Azevedo and M. Romão, "Enterprise Architecture Model : an aprproach proposition - A case study of information systems in the hospitality industry," in Proc. of the Intl. Conf. on Advances in Computing, Electronics and Communication- ACEC 2013, Zurich, 2013.

[2]. M. Lankhorst and H. v. Drunen, "Enterprise Architecture Development and Modelling. Combining TOGAF and ArchiMate," Via Nova Aarchitectura, DE ZILK, 2007.

[3]. R. Rijo, R. Martinho and D. Ermida, "Developing an Enterprise Architecture Proof of Concept in a Portuguese Hospital," in Conference on ENTERprise Information Systems/International Conference on Project MANagement/Conference on Health and Social Care Information Systems and Technologies, 2015.

[4]. M. Lankhorst, Enterprise Architecture at Work: Modelling, Communication, and Analysis. Berlin: Springer, 2005, p. 345.

[5]. ISO/IEC/IEEE, "Survey of Architecture Frameworks" 2014. [Online]. Available: http://www.iso-architecture.org/ieee1471/afs/frameworks-table.html. Diakses tanggal 18 Juni 2020.

[6]. T. O. Group, “Archimate 2.0 Specification”, The Open Group, Berkshire, UK, 2012.

[7]. https://www.opengroup.org, diakses tanggal 18 juni 2020.

[8]. https://pubs.opengroup.org/architecture/archimate3-doc/chap10.html, diakses tanggal 18 juni 2020 